\title{
$\$$ Research Square

\section{Antimicrobial Activity of Pinus Wallachiana Against Fusarium Oxysporum f. sp. Cubense and Analysis of its Fractions by HPLC}

Qurat UI Ain ( $\nabla$ quratulainsatti@yahoo.com )

National Agricultural Research Centre

Shahzad Asad

National Agricultural Research Centre

Karam Ahad

National Agricultural Research Centre

Muhammad Naeem Safdar

National Agricultural Research Centre

Atif Jamal

National Agricultural Research Centre

\section{Research Article}

Keywords: Fusarium oxysporum f. sp. cubense, in vitro assay, Fractions, High Performance Liquid Chromatography, Polyphenolic standards

Posted Date: December 29th, 2021

DOI: https://doi.org/10.21203/rs.3.rs-1146041/v1

License: (c) (i) This work is licensed under a Creative Commons Attribution 4.0 International License.

Read Full License 


\section{Abstract}

Fusarium wilt has ruined banana production and poses a major threat to its industry because of highly virulent Fusarium oxysporum f. sp. cubense (Foc) race 4. The present study focused on the efficacy of Pinus wallachiana and its organic fractions against Foc in in vitro and greenhouse experiments. The presence of polyphenols in the fractions was also investigated using High Performance Liquid Chromatography (HPLC). The in vitro tests carried out for the leaf extract of $P$. wallachiana showed its inhibitory effect on the mycelial growth and based on this evidence, further characterization of fractions were done. Complete mycelial inhibition and the highest zone of inhibition against Foc was observed for the n-butanol fraction in vitro, while the $\mathrm{n}$-hexane and dichloromethane fractions showed lower disease severity index (DSI) in greenhouse experiments. The fractions were further analysed by HPLC using nine polyphenolic standards, namely quercitin, myrecitin, kaempferol, rutin, gallic acid, trans-ferulic acid, coumeric acid, epicatechin and catechin. The highest content of polyphenols, based on standards used, was quantified in the $n$-butanol fraction followed by the ethyl acetate fraction of the leaf extract. This is the first report of antimicrobial activity of Pinus wallachiana against Foc to the best of our knowledge.

\section{Introduction}

Banana (Musa spp.) is tremendously important for millions of cultivators and corporate growers, both for export and subsistence. The yield of commercial bananas across the world is staggeringly affected by Fusarium wilt (Panama disease) of bananas. It is a soil-borne disease whose causative agent is a hyphomycete i.e. Fusarium oxysporum f. sp. cubense ${ }^{1-3}$. Obliteration of Gros Michel by Foc race 1 led to its substitution with resistant Cavendish cultivars that are now susceptible to Foc race 4 specifically Foc TR4 which gained an emplacement from South East Asia to Africa and recently entrenched in Latin America thereby jeopardizing intercontinental banana production ${ }^{4-6}$. Management actions including crop rotation, flood fallowing, organic amendments, intercropping, molecular and biological control, etc have been applied to combat this disease but these measures provide short-term or little success under field conditions that advocate for continuous exploitation of pugnacious methodologies that are oppugnant to the calamitous disease ${ }^{6-10}$.

Various research investigations of plant crude extracts revealed their inhibitory activities against phytopathogens that account for the presence of antimicrobial secondary metabolites as their compositional constituents. Additionally, these secondary metabolites e.g. terpenoids, alkaloids, tannins, saponins, phenylpropanoids, and flavanoids, etc are vital materials in the manufacture of sundry fungicides and pesticides ${ }^{11-15}$. Secondary metabolites signify the adaptive potential of plants against biotic and abiotic stresses ${ }^{16}$. Secondary metabolites structure, optimized through evolution, interferes with microbes molecular targets hence acting as a mechanism for plant defense ${ }^{17}$. Phenolics are the profusely found secondary metabolites in plants ${ }^{18}$. Detection and identification of phenolics have now become an extensive research area because of the evidence that they have an indispensable role in the avoidance of the diseases that are linked to oxidative stress ${ }^{19-21}$. The plant phenolic compounds are 
studied as vital sources of novel antibiotics, insecticides, natural drugs, and herbicides ${ }^{22,23}$. Continuous exploitation of botanicals from various plants and their different parts would be productive in discovering innovatory, environmentally safe antimicrobials that can vanquish the complications of multi-drug resistance and bioaccumulation of pesticides.

Being used as folk medicines, gymnosperm botanicals have also been extensively studied for their antiinflammatory and antimicrobial potential in recent decades. The presence of diverse chemical constituents in these extracts is thought to be responsible for microbial growth inhibition ${ }^{24-27}$. The $P$. wallachiana (commonly called Biar or Blue Pine) is a large cone-bearing evergreen tree belonging to family Pinaceae of gymnosperms with a height up to $35-50 \mathrm{~m}$ and a diameter of $1-1.5 \mathrm{~m}$, having downcurved branches with a straight trunk. Leaves are long $(15-20 \mathrm{~cm})$, slender, in fascicles of 5 , flexible, the adaxial side having multiple bluish-white stomatal lines and abaxial side green ${ }^{28,29}$. It is one of the principal conifers mostly growing in the upper region of mountains associated with other gymnosperms and is regarded as an important medicinal plant ${ }^{30}$. The majority of the research and pharmacognostic studies conducted on $P$. wallachiana strongly supported its antioxidant efficacies ${ }^{31-34}$ and anticancerous potential of $P$. wallachiana needle extract ${ }^{35}$. Antibacterial activity of $P$. wallachiana essential oil against tested bacterial strains ${ }^{36}$ and antifungal efficacy of its essential oil against Fusarium verticillioides ${ }^{37}$, antimicrobial activity of its hydroalcoholic extracts against tested bacterial strains and fungi ${ }^{38}$, antibacterial activity against Acinetobacter baumannii ${ }^{29}$ put forward its antimicrobial potential. Phytochemical studies reported antioxidant activity of $P$. wallachiana extracts that accounts for the presence of plentiful flavanoids and polyphenols in their phytochemical composition ${ }^{32,39}$. Phenolic compounds i.e. chlorogenic acid, catechins, ferulic acid, caffeic acid are wellknown toxic compounds that are much faster concentrated in resistant varieties after their infection by the pathogen ${ }^{40}$. Cell wall phenolics e.g. coumaric acid and trans ferulic acid play a crucial role during plant growth by defending it against stresses including infections and wounding etc ${ }^{41}$. The antiviral potential of catechins and (-)-epicatechin gallate against the influenza virus had been noted. These polyphenols alter the membrane physical properties of the virus ${ }^{42}$. The antimicrobial potential of polyphenols e.g. catechin, gallic acid, ferulic acid, p-coumaric acid, quercitin, and rutin against Xylella fastidiosa had also been described earlier ${ }^{43}$. Similarly, antifungal activities of polyphenolics e.g. phenol, catechin, quercetin, o-coumaric acid, gallic acid, pyrogallic acid, $\rho$-coumaric acid, $\rho$-hydroxy benzoic acid, protocatechuic, salicylic acid, coumarin, and cinnamic acid had been noted ${ }^{44}$. Moreover, powerful antimicrobial activities by polyphenol compounds including kaempferol, gallic acid quercetin, and ellagic acid had been reported ${ }^{45}$. Extracts abundant in antioxidants i.e. ascorbic acid, polyphenols, and flavonoids are a source of cell damage and leaking of biomolecules from the impaired microbial membranes. The present study was designed to investigate the antifungal potential of Pinus wallachiana botanicals against Foc and evaluating its various fractions for the presence of some important polyphenols that might be beneficial for combating Fusarium wilt problem.

\section{Materials And Methods}




\section{Acquisition, revival, and confirmation of fungal culture}

Fusarium oxysporum f. sp. cubense (Foc; TR4) was acquired from the Tissue culture department of National Agricultural Research Centre (NARC); Islamabad, the identity of which has been molecularly confirmed ${ }^{46}$. After the revival of Foc culture on potato dextrose agar (PDA), its morphology was examined; showing 3-5 hyaline, sickle-shaped septate, macroconidia pointed at both ends and borne on single phialides whereas microconidia were found to be mostly hyaline, kidney-shaped, aseptate produced on false heads.

\section{Plant sample and extraction}

A fresh leaf sample of $P$. wallachiana was collected from Ghora gali, Murree (altitude: $2291 \mathrm{~m}$, coordinates $33^{\circ} 54^{\prime} 15^{\prime \prime} \mathrm{N} 73^{\circ} 23^{\prime} 25^{\prime \prime} \mathrm{E}$ ) and after its disinfection with $5 \%$ Clorox, it was shade dried for 30 days and then was mechanically toiled. Powdered leaf sample was stored in labeled plastic jars for the in vitro assays that were performed in the fungal pathology laboratory of NARC. The leaf powder was mixed with ethanol using Erlenmeyer flasks, shaken at 60rpm (revolution per minute) for 48hours and after its filtration excess solvent was removed by the rotary evaporator ${ }^{47}$ thereby dried extract was deposited in a glass vial $^{48}$.

\section{Fungicidal analysis}

Two fold concentrations of the $P$. wallachiana leaf extract $(1.25,2.50,5.0,10,20$, and $40 \mathrm{mg} / \mathrm{mL})$ were amended in autoclaved PDA media for the determination of minimum inhibitory concentration (MIC) and minimum fungicidal concentration (MFC) ${ }^{49}$. With the help of a plunger, $6 \mathrm{~mm}$ wells were made in the center of poisoned plates and Foc plugs were aseptically placed followed by incubation $\left(25 \pm 2^{\circ} \mathrm{C}\right)$ and recording of MIC and MFC after a week's interval. Half minimal inhibitory concentration $\left(\mathrm{IC}_{50}\right)$ was also calculated using the regression equation ${ }^{50}$.

\section{Effect on Foc biomass production}

The liquid culture was used to evaluate the effect of the extract on the production of Foc biomass ${ }^{51}$. Four treatments viz. control (no extract), IC50, MIC, MFC of the extract were separately dissolved in Potato Dextrose Broth $(50 \mathrm{~mL})$. Each flask aseptically received 3-4 plugs of Foc and placed on a rotary shaker (90revolutions $/ \mathrm{min})$ and incubated $\left(25 \pm 2^{\circ} \mathrm{C}\right)$ for a month. Mycelia-containing flasks were autoclaved and media was filtered and mycelia were dried overnight $\left(40^{\circ} \mathrm{C}\right)$ after their washing with distilled water. Dry mycelia containing filter paper were then weighed and percent growth inhibition was calculated by equation (1) for each treatment as:

P.I. = Dry weight of control-Dry weight of sample/Dry weight of control×100 (1)

Where, P.I. $=$ Percent inhibition

\section{Fractionation}


Liquid-liquid fractionation was performed for partitioning of $P$. wallachiana extract using a separating funnel ${ }^{52}$. The $n$-butanol, $n$-hexane, ethyl acetate, and dichloromethane were used as partitioning solvents. Fractionation was done in order of increasing polarity i.e. n-hexane>dichloromethane>ethyl acetate $>n-$ butanol. The $P$. wallachiana extract was dissolved in water and sequential partitioning with $\mathrm{n}$-hexane, dichloromethane, ethyl acetate, and n-butanol was done. Each fraction obtained was dried using a rotary evaporator and after calculation of its percentage yield using equation (2), stored in labeled glass vials.

Yield= weight of dried fraction/initial weight of extract $\times 100(2)$

\section{Food poisoning assay}

Antifungal assay of fractions

Sterilized PDA plates poisoned with each fraction (10\% conc.) and their $5 \%$ respective solvents that served as control were inoculated with Foc plugs $(6 \mathrm{~mm})$ and incubated at $25 \pm 2^{\circ} \mathrm{C}$ in five replicates ${ }^{53}$. When Foc mycelial growth completely covered all the control plates, radial mycelial growth was measured as the percent inhibition of Foc using equation (3).

P.I. = Radial mycelial growth of control-Radial mycelial growth of treatment/ Radial mycelial growth of controlx100 (3)

Where, P.I. = Percent Inhibition

\section{Well diffusion assay}

Spore suspension $\left(10^{6}\right)$ of Foc was spread on the entire surface of sterilized PDA as described earlier ${ }^{54}$. With the help of a cork borer, a hole with a diameter of $6 \mathrm{~mm}$ was punched aseptically in the center of $9 \mathrm{~cm}$ Petri plates (NEST, UK), and $100 \mu \mathrm{L}$ from each fraction (10\%) was introduced into the wells. Plates were incubated at $25 \pm 2^{\circ} \mathrm{C}$ in five replicates for all the treatments. Zone of inhibition (ZOI) started appearing after 3 days of incubation and was measured after one month.

\section{Greenhouse experiment}

Dwarf Cavendish banana plantlets (six weeks old) were acquired from a tissue culture laboratory, NARC. A double pot system $(15 \mathrm{~cm} \times 15 \mathrm{~cm} \times 12 \mathrm{~cm})$ was used for banana plantation with a potting mixture of soil, sand, and peat moss in a 2:1:4 ratio. Millet grains colonized with Foc $(50 \mathrm{~g})$ were packed in the middle of potting mix in each double pot system ${ }^{55}$ to serve as inoculum. Treatments were applied as soil drenching 56 after banana plantlet sowing. Two concentrations of fractions $(20 \mathrm{mg} / \mathrm{mL}$ and $40 \mathrm{mg} / \mathrm{mL})$ and propiconazole $(100 \mu \mathrm{g} / \mathrm{mL}$ and $200 \mu \mathrm{g} / \mathrm{mL})$ along with their respective controls were used as soil drench treatments.

Three drenching's were applied during the greenhouse experiment and assessment of visual symptoms was done after each drenching. Evaluation of disease severity based on visual symptoms was measured 57 and Disease Severity Index (DSI) for each treatment was calculated. 


\section{HPLC analysis of fractions}

Nine polyphenolic standards were used in HPLC analysis for their detection and quantification in $P$. wallachiana fractions ${ }^{58}$. Fractions $(1 \mathrm{mg} / \mathrm{mL}$ concentration) were filtered with the help of a Membrane filter $(0.45 \mu \mathrm{m})$ and analyzed on Perkin Elmer HPLC system equipped with LC 295 UV/VIS detector, binary LC pump, and a reverse phase C18 column $(4.6 \mathrm{~mm} \times 250 \mathrm{~mm}, 5 \mu \mathrm{m})$. Solvent A (acetonitrile) and solvent B

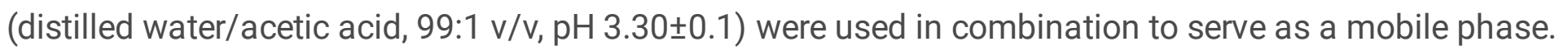
Linear gradient mobile phase with a flow rate of $1 \mathrm{~mL} / \mathrm{min}$ and $20 \mu \mathrm{L}$ injection volume of the sample was employed with detector setting at $285 \mathrm{~nm}$ and $370 \mathrm{~nm}$ for phenolics and flavanoids respectively. Gallic acid, epicatechin, catechin, trans-ferulic acid, and trans-p-coumaric acid were used as phenolic standards ( $\wedge$ max: $285 \mathrm{~nm}$ ). The conditions of gradient program used for phenolic acid separation were $20 \%$ A (5 $\mathrm{min}$ ), $20 \%$ A ( $5 \mathrm{~min}$ ), $80 \%$ A (10 min), 20\% A (5 min). Flavonoids standards ( $\wedge$ max: $370 \mathrm{~nm}$ ) used were Rutin, Myrecitin, Quercitin and Kaempferol and flavanoids were separated using the program: $20 \%$ A (5 $\mathrm{min}), 20 \% \mathrm{~A}(5 \mathrm{~min}), 80 \% \mathrm{~A}(7 \mathrm{~min}), 20 \% \mathrm{~A}$ (8 min). The analytes were identified by comparing the Rt (retention time) and spike samples with polyphenolic standards and subsequent quantification of phenolic compounds was determined.

\section{Results}

\section{Fungicidal analysis}

The MIC and MFC of $P$. wallachiana extract against Foc were determined to be $20 \mathrm{mg} / \mathrm{mL}$ and $40 \mathrm{mg} / \mathrm{mL}$ respectively while $\mathrm{IC}_{50}$ was calculated to be $6.09 \mathrm{mg} / \mathrm{mL}$ using regression equation (Table 1 ).

Table 1

Determination of Half minimal inhibitory concentration $\left(\mathrm{IC}_{50}\right)$ of $P$. wallachiana against Foc

\begin{tabular}{|lllll|}
\hline $\begin{array}{l}P . \text { wallachiana leaf extract } \\
\text { (concentration in } \mathrm{mg} / \mathrm{mL} \text { ) }\end{array}$ & Percent Inhibition & $\mathrm{IC}_{50}$ & $\mathbf{R}^{2}$ & Regression equation \\
\hline 1.25 & $25 \pm 1.20$ & 6.09 & 0.9435 & $\mathrm{y}=3.7999 \mathrm{x}+26.853$ \\
\hline 2.5 & $32.2 \pm 0.7$ & & & \\
\hline 5 & $54.5 \pm 0.5$ & & & \\
\hline 10 & $71.6 \pm 0.3$ & & & \\
\hline 20 & $98.3 \pm 0.4$ & & & \\
\hline
\end{tabular}

\section{Effects on biomass production}

Although $P$. wallachiana extract supplemented treatments (IC $\left.\mathrm{C}_{50}, \mathrm{MIC}, \mathrm{MFC}\right)$ showed considerable reduction in Foc biomass compared to the control but maximum biomass reduction and $100 \%$ inhibition was found for MFC i.e. $40 \mathrm{mg} / \mathrm{mL}$ (Table 2). 
Table 2

Effect of $P$. wallachiana extract on the biomass production of Foc

\begin{tabular}{|lll|}
\hline \multirow{2}{*}{ Treatments } & \multicolumn{2}{l|}{ Biomass Production } \\
\cline { 2 - 3 } & dry weight (mg) & Percent inhibition \\
\hline Control (0) & 158 & 0.00 \\
\hline IC $_{50}(6.09)$ & 58.7 & 62.9 \\
\hline MIC (20) & 2.4 & 98.5 \\
\hline MFC (40) & 0 & 100 \\
\hline
\end{tabular}

Fractions of P. wallachiana

\section{The percentage yield of fractions}

Maximum yield was recorded for dichloromethane fraction (27.8\%) followed by n-butanol (25.12\%), ethyl acetate $(24.68 \%)$, and $n$-hexane (21.8\%) fractions (Table 3 ).

Table 3

Percentage yield of four fractions of $P$. wallachiana prepared through liquid-liquid fractionation

\begin{tabular}{|l|ll|}
\hline \multicolumn{1}{|l|}{ Fractions } & Percentage yield (\%) \\
\hline n-Hexane fraction & 21.8 \\
\hline Dichloromethane fraction & 27.8 \\
\hline Ethyl acetate fraction & 24.68 \\
\hline n-Butanol fraction & 25.12 \\
\hline
\end{tabular}

In the food poisoning assay, all fractions of $P$. wallachiana effectively inhibited mycelial growth of Foc compared to the solvent controls. The n-butanol fraction of $P$. wallachiana completely inhibited mycelial growth (i.e.100\%) followed by dichloromethane fraction (75.96\%), n-hexane fraction (68.93), and ethyl acetate $(57.26 \%)$ fraction (Table 3 \& Supplementary Table S1-S2). In well diffusion assay, maximum zone of inhibitions was measured for n-butanol $(24.4 \mathrm{~mm})$ and dichloromethane fraction $(23.8 \mathrm{~mm})$ while $\mathrm{n}$ hexane and ethyl acetate recorded $21 \mathrm{~mm}$ and $18.6 \mathrm{~mm}$ ZOI respectively (Table 4 \& Supplementary Table S3-S4). 
Table 4

Percent inhibition and zone of inhibition values recorded for $P$. wallachiana fractions against Foc using in vitro assays.

\begin{tabular}{|lll|}
\hline Treatments & Percent inhibition & Zone of Inhibition (ZOI) \\
\hline n-Hexane control & $0.00 \pm 0.00^{\mathrm{E}}$ & $0.00 \pm 0.00^{\mathrm{D}}$ \\
\hline $\mathrm{n}$-Hexane fraction & $68.93 \pm 0.47^{\mathrm{C}}$ & $21.0 \pm 0.92^{\mathrm{B}}$ \\
\hline Dichloromethane control & $0.00 \pm 0.00^{\mathrm{E}}$ & $0.00 \pm 0.00^{\mathrm{D}}$ \\
\hline Dichloromethane fraction & $75.96 \pm 0.30^{\mathrm{B}}$ & $23.80 \pm 1.12^{\mathrm{A}}$ \\
\hline Ethyl acetate control & $0.00 \pm 0.00^{\mathrm{E}}$ & $0.00 \pm 0.00^{\mathrm{D}}$ \\
\hline Ethyl acetate fraction & $57.26 \pm 0.39^{\mathrm{D}}$ & $18.60 \pm 0.51^{\mathrm{C}}$ \\
\hline n-butanol control & $0.00 \pm 0.00^{\mathrm{E}}$ & $0.00 \pm 0.00^{\mathrm{D}}$ \\
\hline n-butanol fraction & $100 \pm 0.00^{\mathrm{A}}$ & $24.40 \pm 0.43^{\mathrm{A}}$ \\
\hline $\begin{array}{l}\text { Data Presented as Mean value of five replicates } \pm \text { represents Standard error. Significant differences } \\
\text { among treatments were indicated by different superscript letters within individual column }\end{array}$ \\
\hline
\end{tabular}

\section{Greenhouse experiment of fractions}

First severity scoring (based on a 1-5 scale) was performed after a month of 1st drenching. Highest disease severity index (DSI) value, calculated from the severity scores, was recorded for n-butanol fraction $(40 \mathrm{mg} / \mathrm{mL})$ while $n$-hexane fraction $(20 \mathrm{mg} / \mathrm{mL})$ along with dichloromethane fraction $(20 \mathrm{mg} / \mathrm{mL})$ displayed lowest DSI. Second drenching was applied after recording first severity scoring and second severity scoring was performed after two months of 2 nd drenching. Maximum DSI i.e. $100 \%$ value was calculated by all solvent control treatments including fungicide $(200 \mu \mathrm{g} / \mathrm{mL})$ and $\mathrm{n}$-butanol fraction $(20 \mathrm{mg} / \mathrm{mL})$. After second severity scoring third drenching was applied. Third severity scoring was performed after four months of 3rd drenching. Lowest DSI was noted for dichloromethane $(20 \mathrm{mg} / \mathrm{mL})$ and hexane $(40 \mathrm{mg} / \mathrm{mL})$ fractions with $60 \%$ values. Comparison of the DSI of different treatments, calculated at 3 different intervals revealed that progress of wilting was delayed in the case of dichloromethane $(20 \mathrm{mg} / \mathrm{mL})$ and hexane $(40 \mathrm{mg} / \mathrm{mL})$ fractions. Except for $\mathrm{n}$-hexane, all the other fractions recorded maximum DSI in their higher concentration i.e. $40 \mathrm{mg} / \mathrm{mL}$ (Table 5 \& Supplementary Table S5-S10). 
Table 5

Comparison of the three severity scorings and their respective disease severity indices calculated for banana plants drenched with fraction treatments in three different intervals during greenhouse

experiment

\begin{tabular}{|c|c|c|c|c|c|c|}
\hline \multirow[t]{2}{*}{ Treatments } & \multicolumn{2}{|l|}{ First drenching } & \multicolumn{2}{|c|}{ Second drenching } & \multicolumn{2}{|c|}{ Third drenching } \\
\hline & $\begin{array}{l}1^{\text {ST }} \text { Severity } \\
\text { Scores }\end{array}$ & DSI & $\begin{array}{l}2^{\mathrm{ND}} \text { Severity } \\
\text { Scores }\end{array}$ & DSI & $\begin{array}{l}3^{\mathrm{RD}} \text { Severity } \\
\text { Scores }\end{array}$ & DSI \\
\hline Simple Control & $4.286 \pm 0.29^{\mathrm{BC}}$ & 85.71 & $5.000 \pm 0.00^{\mathrm{A}}$ & 100 & $5.000 \pm 0.00^{\mathrm{A}}$ & 100 \\
\hline $\begin{array}{l}\text { Fungicide }(100 \mu \mathrm{g} / \mathrm{ml}) \\
\text { Conc. } 1\end{array}$ & $3.429 \pm 0.20^{\mathrm{DE}}$ & 68.57 & $4.000 \pm 0.31^{\mathrm{BC}}$ & 80 & $3.857 \pm 0.34^{\mathrm{B}}$ & 77.14 \\
\hline $\begin{array}{l}\text { Fungicide }(200 \mu \mathrm{g} / \mathrm{ml}) \\
\text { Conc. } 2\end{array}$ & $4.286 \pm 0.29^{\mathrm{BC}}$ & 85.7 & $5.000 \pm 0.00^{A}$ & 100 & $5.000 \pm 0.00^{A}$ & 100 \\
\hline Hexane Control & $3.714 \pm 0.29^{\mathrm{CDE}}$ & 74.28 & $5.000 \pm 0.00^{\mathrm{A}}$ & 100 & $5.000 \pm 0.00^{\mathrm{A}}$ & 100 \\
\hline $\begin{array}{l}\text { Hexane }(20 \mathrm{mg} / \mathrm{ml}) \\
\text { Conc. } 1\end{array}$ & $2.286 \pm 0.18^{G}$ & 45.71 & $2.571 \pm 0.37^{F}$ & 51.43 & $3.571 \pm 0.37^{\mathrm{BC}}$ & 71.43 \\
\hline $\begin{array}{l}\text { Hexane }(40 \mathrm{mg} / \mathrm{ml}) \\
\text { Conc. } 2\end{array}$ & $2.571 \pm 0.20^{G}$ & 51.43 & $2.571 \pm 0.30^{F}$ & 51.43 & $3.000 \pm 0.22^{C}$ & 60 \\
\hline $\begin{array}{l}\text { Dichloromethane } \\
\text { Control }\end{array}$ & $4.286 \pm 0.36^{\mathrm{BC}}$ & 85.71 & $5.000 \pm 0.00^{A}$ & 100 & $5.000 \pm 0.00^{A}$ & 100 \\
\hline $\begin{array}{l}\text { Dichloromethane } \\
\text { (20mg/ml) Conc. } 1\end{array}$ & $2.286 \pm 0.29^{G}$ & 42.85 & $2.857 \pm 0.26^{\mathrm{EF}}$ & 57.14 & $3.000 \pm 0.38^{C}$ & 60 \\
\hline $\begin{array}{l}\text { Dichloromethane } \\
(40 \mathrm{mg} / \mathrm{ml}) \text { Conc. } 2\end{array}$ & $3.571 \pm 0.20^{\mathrm{DE}}$ & 71.43 & $3.714 \pm 0.29^{C D}$ & 74.28 & $3.571 \pm 0.53^{\mathrm{BC}}$ & 71.43 \\
\hline Ethyl acetate Control & $4.000 \pm 0.22^{\mathrm{BCD}}$ & 80 & $5.000 \pm 0.00^{\mathrm{A}}$ & 100 & $5.000 \pm 0.00^{\mathrm{A}}$ & 100 \\
\hline $\begin{array}{l}\text { Ethyl acetate } \\
(20 \mathrm{mg} / \mathrm{ml}) \text { Conc. } 1\end{array}$ & $2.714 \pm 0.18^{\mathrm{FG}}$ & 54.28 & $4.571 \pm 0.30^{\mathrm{AB}}$ & 60 & $4.286 \pm 0.29^{A B}$ & 71.43 \\
\hline $\begin{array}{l}\text { Ethyl acetate } \\
(40 \mathrm{mg} / \mathrm{ml}) \text { Conc. } 2\end{array}$ & $3.286 \pm 0.29^{\mathrm{EF}}$ & 65.71 & $5.000 \pm 0.00^{\mathrm{A}}$ & 65.71 & $5.000 \pm 0.00^{\mathrm{A}}$ & 74.28 \\
\hline n-butanol Control & $4.571 \pm 0.20^{\mathrm{AB}}$ & 91.43 & $5.000 \pm 0.00^{\mathrm{A}}$ & 100 & $5.000 \pm 0.00^{\mathrm{A}}$ & 100 \\
\hline $\begin{array}{l}\text { n-butanol }(20 \mathrm{mg} / \mathrm{ml}) \\
\text { Conc. } 1\end{array}$ & $4.429 \pm 0.20^{\mathrm{AB}}$ & 88.57 & $3.000 \pm 0.31^{\mathrm{EF}}$ & 91.43 & $3.571 \pm 0.37^{\mathrm{BC}}$ & 85.71 \\
\hline $\begin{array}{l}\text { n-butanol }(40 \mathrm{mg} / \mathrm{ml}) \\
\text { Conc. } 2\end{array}$ & $5.000 \pm 0.00^{\mathrm{A}}$ & 100 & $3.286 \pm 0.29^{\mathrm{DE}}$ & 100 & $3.714 \pm 0.36^{\mathrm{BC}}$ & 100 \\
\hline
\end{tabular}


Identification and quantification of polyphenolic compounds i.e. phenolic acids and flavonoids were determined in the four fractions of $P$. wallachiana using HPLC analysis. Identification and quantification of phenolics $(285 \mathrm{~nm})$ and flavanoids $(370 \mathrm{~nm})$ was according to retention time (RT) and peak spectral characteristics against those of standards. Detection of Polyphenolic compounds compared to standards and the overall polyphenolic content of $P$. wallachiana leaf extract varied in different fractions, as evident from the data (Table 6 \& Supplementary Table 11S). The HPLC chromatograms of polyphenolic standards and two fractions of $P$. wallachiana i.e. ethyl acetate and $\mathrm{n}$-butanol showed that all the polyphenolic compounds were detected in the n-butanol and ethyl acetate fractions except for rutin. Likewise, only quercitin and ferulic acid were detected in the n-hexane fraction while dichloromethane fraction detected all polyphenolic compounds except rutin, myrecitin and catechin (Fig. 1 \& Supplementary Fig. S1).

Table 6

Phenolic compound profile of the four fractions of $P$. wallachiana quantified through HPLC analysis

\begin{tabular}{|lllll|}
\hline $\begin{array}{l}\text { Phenolic compounds } \\
\text { (mg/g of extract) }\end{array}$ & $\begin{array}{l}\text { n-hexane } \\
\text { fraction }\end{array}$ & $\begin{array}{l}\text { Dichloromethane } \\
\text { fraction }\end{array}$ & $\begin{array}{l}\text { Ethyl acetate } \\
\text { fraction }\end{array}$ & $\begin{array}{l}\text { n-Butanol } \\
\text { fraction }\end{array}$ \\
\hline Gallic acid & N.D. & $0.10 \pm 0.0033$ & $3.57 \pm 0.016$ & $11.57 \pm 0.0089$ \\
\hline Catechin & N.D. & N.D. & $13.46 \pm 0.007$ & $33.44 \pm 0.0087$ \\
\hline Epicatechin & N.D. & $1.19 \pm 0.0053$ & $3.23 \pm 0.0090$ & $16.74 \pm 0.0074$ \\
\hline Coumeric acid & N.D. & $0.61 \pm 0.0043$ & $2.94 \pm 0.0068$ & $4.33 \pm 0.0034$ \\
\hline Trans-Ferulic acid & $0.13 \pm 0.0004$ & $0.61 \pm 0.0037$ & $2.84 \pm 0.0039$ & $0.52 \pm 0.0018$ \\
\hline Rutin & N.D. & N.D. & N.D. & N.D. \\
\hline Myrecitin & N.D. & N.D. & $2.15 \pm 0.0044$ & $0.74 \pm 0.0064$ \\
\hline Quercitin & $0.04 \pm 0.00001$ & $0.06 \pm 0.0005$ & $7.9 \pm 0.0056$ & $0.52 \pm 0.0041$ \\
\hline Kaempferol & N.D. & $0.09 \pm 0.0034$ & $7.81 \pm 0.011$ & $0.66 \pm 0.0058$ \\
\hline $\begin{array}{l}\text { Total polyphenolic } \\
\text { content }\end{array}$ & $\mathbf{0 . 1 7 m g / g}$ & $\mathbf{2 . 6 6 m g} / \mathbf{g}$ & $43.90 \mathrm{mg} / \mathrm{g}$ & $\mathbf{6 8 . 5 2 m g} / \mathrm{g}$ \\
\hline Values are mean of three replications. N.D. Not detected & & \\
\hline
\end{tabular}

Highest gallic acid $(11.57 \mathrm{mg} / \mathrm{g})$, catechin $(33.44 \mathrm{mg} / \mathrm{g})$, epicatechin $(16.74 \mathrm{mg} / \mathrm{g})$ and coumeric acid $(4.33 \mathrm{mg} / \mathrm{g})$ were detected in $\mathrm{n}$-butanol fraction whereas highest ferulic acid $(2.84 \mathrm{mg} / \mathrm{g})$, myrecitin $(2.15 \mathrm{mg} / \mathrm{g})$, quercitin $(7.9 \mathrm{mg} / \mathrm{g})$ and kaempferol $(7.81 \mathrm{mg} / \mathrm{g})$ were quantified in ethyl acetate fraction. Maximum polyphenolic content, based on 9 polyphenol standards, were determined for $\mathrm{n}$-butanol fraction of $P$. wallachiana $(68.52 \mathrm{mg} / \mathrm{g}$ of extract) followed by ethyl acetate fraction $(43.90 \mathrm{mg} / \mathrm{g}$ of extract) (Table $6)$. 


\section{Discussions}

Due to the ethnopharmacological properties of plants, up to $50 \%$ of novel drugs are procured from natural sources 59,60 . Distinct plants and their different parts are administered in various modes for the treatment of infectious pathologies ${ }^{61-63}$. Active constituents of botanicals may directly take action on the pathogen or induce systemic resistance in the host plant ensuing in the decrement of disease development ${ }^{64,65}$. In the present investigation antimicrobial potential of Pinus walliachina; a gymnosperm was explored against one of the most devastating pathogen Fusarium oxysporum $\mathrm{f}$. $\mathrm{sp}$. cubense. Initial screening was carried out with $P$. walliachina leaf extracts for testing the antimicrobial potential. Results indicated that extract effectively inhibited the growth of Foc and based on these observations further experiments were initiated which included extraction of fractions using four solvents viz. hexane, dichloromethane, ethyl acetate and n-butanol and their potential to inhibit fungus in in vitro and green house. Both the assay results verified the effectiveness of $P$. walliachina and therefore, this study demonstrates first report of antimicrobial activity of $P$. walliachina against Foc to the best of our knowledge. HPLC was also carried to further characterize all fractions and nine standards were used for the said purpose.

Leaf extract completely inhibited the mycelial growth of Foc and this observation was similar to the ones made previously where antifungal efficacy of extracts from distinct species associated with different families of gymnosperms was demonstrated ${ }^{26}$ and also the efficacy of botanicals extracted from $P$. walliachina exhibited prominent antifungal, antibacterial and insecticidal activities ${ }^{31,37,38,66}$. The four fractions of $P$. walliachina recorded significant percent inhibition and zone of inhibition against Foc in the poisoned food and well diffusion assays respectively. These results are in consistent with another study where fractions of $P$. walliachina crude leaf extract showed insecticidal (ethyl acetate) and antimicrobial (n-hexane) activities against Rhyzopertha dominica and Microsporum cannis respectively ${ }^{67}$. The $\mathrm{n}$ butanol followed by dichloromethane fraction was found to most efficient treatments. However, the inhibitory potential of the four fractions was variable that might be due to different types of solvents used. It is reported that type of plant/plant part and type of extraction solvent are reason for the variation of phytochemical composition of various extracts ${ }^{68}$.

In the greenhouse assay the $n$-hexane fraction treatment with $40 \mathrm{mg} / \mathrm{mL}$ and dichloromethane fraction treatment with $20 \mathrm{mg} / \mathrm{mL}$ concentrations were found effective. Complete mycelial inhibition of Foc in the in vitro assay was observed in $\mathrm{n}$-butanol fraction whereas in green house experiment same fraction $(40 \mathrm{mg} / \mathrm{mL})$ recorded $100 \% \mathrm{DSI}$ after one month of its very first drenching. It was noticed that polar fractions with their higher concentrations recorded comparatively higher DSI values suggesting that with the high polarity of fraction its phytotoxicity to banana plantlets also increases. Polar fractions might have such phytochemicals that were not only detrimental to Foc but also had a phytotoxic effect on banana plantlets. A similar phytotoxicity phenomenon was described in an earlier study while working with different concentrations of chemical treatments (sterilant and fungicide) as soil drenching. All chemicals with $50 \mu \mathrm{g} / \mathrm{mL}$ concentration developed severe phytotoxicity symptoms while at lower 
concentrations none of the banana plantlets expressed phytotoxicity ${ }^{56}$. Similarly, in another study significant phytotoxicity of various fractions of $P$. wallachiana leaves at $500 \mu \mathrm{g} / \mathrm{mL}$ were observed ${ }^{67}$. It can be concluded therefore that polar fractions should be used with comparatively lower concentrations i.e. less than $20 \mathrm{mg} / \mathrm{mL}$ to decrease the $\mathrm{DSI}$ values.

The HPLC analysis of $P$. wallachiana fractions was done for the identification and quantification of polyphenolics using nine standards and it confirmed the presence of most of polyphenolic compounds in $P$. wallachiana fractions. All polyphenolic compounds except rutin were detected in the ethyl acetate and n-butanol fraction of $P$. wallachiana that commensurates with past study describing that all pine extracts contain a high number of polyphenols ${ }^{69-71}$. Dichloromethane fraction detected all polyphenolic compounds except rutin, myrecitin and catechin while n-hexane fraction only detected ferulic acid and quercitin. Epicatechin, gallic acid, coumeric acid, and catechin were recorded highest in n-butanol fraction while kaempferol, ferulic acid, quercitin and myrecitin were detected highest in ethyl acetate fraction. The highest polyphenolic content based on the 9 polyphenolic standards was quantified for $P$. wallachiana $\mathrm{n}$ butanol fraction followed by ethyl acetate. An earlier study found quercetin as the most abundant flavonol in n-butanol fraction (15.714\%) of $P$. wallachiana methanol leaf extract using HPLC 72,73 . Similarly high amounts of polyphenolics mainly taxifolin and catechins were found to be the main reason for the antioxidant and biological activity of Pinus species ${ }^{74}$. Moreover, phenolics and sulfur present in the plant extract contributed to the cell death of Foc TR4 by inducing oxidative bursts, mitochondrial impairment, and depolarization of plasma membrane ${ }^{75}$. The production of phenolics in the resistant varieties of banana restricts pathogen to infected vessels due to lignifications of obstructions resulted from initial pathogen-induced occlusion reaction ${ }^{76}$. There is evidence that trans-ferulic acid and $p$ coumaric acid significantly inhibiting the mycelial growth of Foc TR4 ${ }^{77}$. The presence of the polyphenolic compounds quantified in the fractions of $P$. wallachiana, is the most probable reason for its mycelial inhibition activity against Foc.

\section{Conclusion}

This study exclusively evaluated $P$. wallachiana and its fractions efficacy against Foc and noted significant antifungal activity using in vitro and greenhouse assays, suggesting their potential role in the management of vascular wilt of bananas. It is established that polyphenolic compounds have potent efficacy against phytopathogens as we know this fact that phenolic compounds are active in plant defense response. HPLC analysis of $P$. wallachiana fractions revealed the presence of most of the compounds (based on 9 polyphenolic standards), with their maximum quantification in n-butanol and ethyl acetate fraction. The existence of such important polyphenols with known antimicrobial efficacy accounts for the antifungal activity of the $P$. wallachiana fractions against Foc that is contemporary scientific information never reported prior. The research study strongly recommends $P$. wallachiana and its fractions be exploited further for the presence of valuable compounds that can make a breakthrough for control of Panama wilt disease soon. 


\section{Declarations}

\section{Acknowledgements}

Author is thankful to Higher Education Commission, for their financial support. Special thanks to Plant and Environmental Protection department and Ecotoxicology department, NARC for arrangement of laboratory facilities for current study.

\section{Author contributions}

Conceptualization- Q.U.A., S.A. and A.J.; Data recording and interpretation- Q.U.A., K.A. and M.N.S.; Writing- original draft preparation- Q.U.A. and A.J.; review and editing- A.J. and Q.U.A.

\section{Statement of compliance}

Experimental research and field study on the plant is in compliance with institutional, national and international guidelines and legislations. The leaves were collected after the permission from the land owned by my relatives and they were duly informed about the purpose of collection.

\section{Fundings}

Higher Education Commission (HEC), Pakistan

\section{Conflicts of interest/Competing interests}

No conflicts of interest

\section{Availability of data and material}

Yes

\section{Code availability}

Not applicable

\section{References}

1. Grimm, D. Plant genomics. A bunch of trouble. Science 322, 1046-1047 (2008). 
2. Ploetz, R. C. Fusarium wilt of banana is caused by several pathogens referred to as Fusarium oxysporumf. sp. cubense. Phytopathology 96, 653-656, DOI: 10.1094/PHYTO-96-0653 (2006).

3. Ploetz, R. C. Management of Fusarium wilt of banana: a review with special reference to tropical race 4. Crop Prot. 73, 7-15 (2015).

4. Wen, T. et al. Effects of water regime, crop residues, and application rates on control of Fusarium oxysporum f. sp. cubense. J. Environ. Sci. 31, 30-37, DOI: 10.1016/j.jes.2014.11.007 (2015).

5. Maymon, M., Sela, N., Shpatz, U., Galpaz, N. \& Freeman, S. The origin and current situation of Fusarium oxysporum f. sp. cubense tropical race 4 in Israel and the Middle East. Sci. Rep. 10,1-11 (2020).

6. Viljoen, A., Ma, L-J. \& Molina, A. B. Fusarium wilt (Panama disease) and monoculture in banana production: resurrgence of a century-old disease in Emerging plant diseases and global food security (eds. Ristaino, J.B. \& Records, A.) American Phytopathological Society, St. Paul, MN (2020).

7. Zhang, H., Mallik A. \& Zeng, R. S. Control of Panama disease of banana by rotating and intercropping with chineese chive (Allium tuberosum Rottler): Role of plant volatiles. J. Chem. Ecol. DOI: 10.1007/s10886-013-0243-x (2013).

8. Gnanasekaran, P., Salique, S. M., Panneerselvam, A. \& Umamagheswari, K. In vitro biological control of Fusarium oxysporum f. sp. cubense by using some Indian medicinal plants. Int. J. Curr. Res. Aca. Rev. 3(11), 107-116 (2015).

9. Katan, J. Diseases caused by soil-borne pathogens: biology, management and challenges. J. Plant Pathol. 99, 305-315 (2017).

10. Bubici, G. et al. Biological control agents against Fusarium wilt of banana. Front. Microbiol. 10, 616, DOI: 10.3389/fmicb.2019.00616 (2019).

11. Doughari, J. H., Human, I. S., Bennade, S. \& Ndakidemi, P. A. Phytochemicals as chemotherapeutic agents and antioxidants: possible solution to the control of antibiotic resistant verocytotoxin producing bacteria. Journal of Medicinal Plants Research 3(11), 839-848 (2009).

12. Saravanakumar, D., Karthiba, L., Ramjegathesh, R., Prabakar, K. \& Raguchander, T. Characterization of bioactive compounds from botanicals for the management of plant diseases in Sustainable crop disease management using natural products (eds. Ganesan, S., Vadivel, K. \& Jayaraman, J.) CAB International (2015).

13. Thorat, P., Kshirsagar, R., Sawate, A. \& Patil, B. Effect of lemongrass powder on proximate and phytochemical content of herbal cookies. J. Pharmacogn. Phytochem. 6, 155-159 (2017).

14. Masarirambi, M. T. et al. Traditional/indigenous vegetables of the kingdom of eswatini: biodiversity and their importance: a review. J. Exp. Agric. Int. 42, 204-215 (2020).

15. Nxumalo, K. A., Aremu, A. O. \& Fawole, O.A. Potentials of medicinal plant extracts as an alternative to synthetic chemicals in postharvest protection and preservation of horticultural crops: a review. Sustainability 13, 5897, https:// doi. org/ 10.3390/ su13115897 (2021).

16. Stefanovic, O. \& Comic, L. Synergistic antibacterial interaction between Melissa officinalis extracts and antibiotics. J App Pharm Sci. 2, 1-5 (2012). 
17. Wink, M., Ashour, M. L. \& El-Readi, M. Z. Secondary metabolites from plants inhibiting ABC transporters and reversing resistance of cancer cells and microbes to cytotoxic and antimicrobial agents. Front Microbiol. 3, 1-15 (2012).

18. Pereira, D. M., Valentao, P., Pereira, J. A. \& Andrade, P. B. Phenolics: from chemistry to biology. Molecules 2202-2211 (2009).

19. Marchand L. L., Murphy, S. P., Hankin, J. H., Wilkens, L. R. \& Kolonel, L. N. Intake of flavonoids and lung cancer. J. Natl. Cancer Inst. 92, 154-160 (2000).

20. Chanwitheesuk, A., Teerawutgulrag, A. \& Rakariyatham, N. Screening of antioxidant activity and antioxidant compounds of some edible plants of Thailand. Food Chem. 92, 491-497 (2005).

21. Dai, J. \& Mumper, R. J. Plant phenolics: Extraction, analysis and their antioxidant and anticancer properties. Molecules 15, 7313-7352, DOI:10.3390/ molecules15107313 (2010).

22. Cozier, A., Cifford, M. N. \& Ashihara, H. Plant secondary metabolites - occurrence, structure and role in the human diet. Blackwell publishing, 209 (2014).

23. Jalaj, A.V. \& Radhamany, P. M. Identification and quantification of phenolic compounds from Operculina turpethum (L.) Silva manso leaf by HPLC method. IJPSR 7(4), 1656-1661 (2016).

24. Harborne, J. B. \& Baxter, H. The chemical dictionary of economic plants. Wiley and Sons,Chichester, p.582 (2001).

25. Watanabe, K. \& Fukao, T. Antibacterial effects of unipe Cephalotaxus harringtonia fruit extract on gram-positive bacteria. J. Jpn. Soc. Food Sci. Tech. 56, 533-540 (2009).

26. Joshi, S. \& Sati, S. C. Antifungal potential of gymnosperms: a review in Contribution to the mycological progress (eds. Sati, S.C. \& Belwal, M.) Daya publishing house. p.333-345, DOI:10.13140/RG.2.1.3408.0084 (2012).

27. Joshi, S., Sati, S. C. \& Kumar, P. Antibacterial potential and ethnomedical relevance of Kumaun himalayan gymnosperms. JPHYTO 5(5), 190-200 (2016).

28. Orwa, C., Mutua, A., Kindt, R., Jamnadass, R. \& Anthony, S. Agroforestree database:a tree reference and selection guide version 4.0. http:// www. worldagroforestry. org/sites/treedbs/ treedatabases. asp (2009).

29. Khan, N. et al. Pinus wallichiana-synthesized silver nanoparticles as biomedical agents: in-vitro and in-vivo approach. Green Chem. Lett. Rev. 13, 69-82, https:// doi. org/10. 1080/ 17518253.2020.1733105 (2020).

30. Rahman, I. U., Khan, N. \& Ali, K. Variability assessment of some morphological traits among blue pine (Pinus wallichiana) communities in Hindukush ranges of SWAT, Pakistan. Pak J Bot. 49(4), 13511357 (2017).

31. Sharma, A., Sharma, L. \& Goyal, R. A review on Himalayan pine species: ethnopharmacological, phytochemical and pharmacological aspects. Pharmacogn J. 10(4), 611-619, DOI: 10.5530/pj.2018.4.100 (2018). 
32. Sinha, D. A review on ethnobotanical, phytochemical and pharmacological profile of Pinus wallichiana A.B. Jacks. Pharmacogn J. 11(4), 624-631, DOI: 10.5530/pj.2019.11.100 (2019).

33. Khan, N. et al. Potential cytotoxic and mutagenic effect of Pinus wallichiana, Daphne oleiodes and Bidens chinensis. Saudi Journal of Biological Sciences 28(8), 4793-4799, https:// doi.org/ 10.1016/j. sjbs.2021.05.005 (2021).

34. Emami, S.A., Shahani, A. \& Khayyat, M.H. Antioxidant activity of leaves and fruits of cultivated conifers in Iran. Jundishapur Journal of Natural Pharmaceutical Products 8(3), 113-7, DOI: 10.17795/jjnpp-9670 (2013)

35. Joshi, S. et al. Aqueous extract of Pinus wallichiana inhibits proliferation of cervical cancer cell line HeLa and represses the transcription of angiogenic factors HIF1a and VEGF. Eco. Env. \& Cons. 26, S12-S19 (2020).

36. Qadir, M. \& Shah, W. A. Comparative GC-MS analysis, antioxidant, antibacterial and anticancer activity of essential oil of Pinus wallichaina from Kashmir, India. Elixir Appl. Chem. 72, 25819-25823 (2014).

37. Dambolena, J. S. et al. Composition, antifungal and antifumonisin activity of Pinus wallichiana, Pinus monticola and Pinus strobus essential oils from Patagonia Argentina. Journal of Essential Oil Bearing Plants 19(7), 1769-1775, http://dx.doi.org/10.1080/0972060X.2015.1038090 (2016).

38. Sharma, A., Goyal, R. \& Sharma, L. Potential biological efficacy of Pinus plant species against oxidative, inflammatory and microbial disorders. BMC Complementary and Alternative Medicine 16, 35, DOI: 10.1186/s12906-016-1011-6 (2016).

39. Sharma, P. et al. Antioxidant and phytochemical analysis of volatile oil and extracts of Pinus wallichiana. MOJ Biol Med. 4(2), 37-40 (2019).

40. Agrios, G. N. How plants defend themselves against pathogens. In: Plant pathology 5th edition. Elsevier Academic Press (2005).

41. Naczk, M. \& Shahidi, F. Review: extraction and analysis of phenolics in food. J. Chromatogr. A. 1054, 95-111 (2004).

42. Song, J. M., Lee K. H. \& Seong, B. L. Antiviral effect of catechins in green tea on influenza virus. Antiviral Res. 68, 66-74 (2005).

43. Maddox, C. E., Laur, L. M. \& Tian, L. Antibacterial activity of phenolic compounds against the phytopathogen Xylella fastidiosa. Curr. Microbiol. 60, 53-58, DOI: 10.1007/s00284-009-9501-0 (2010).

44. El-Khateeb, A. Y., Elsherbiny, E. A., Tadros, L. K., Ali, S. M. \& Hamed, H. B. Phytochemical analysis and antifungal activity of fruit leaves extracts on the mycelial growth of fungal plant pathogens. Journal of Plant Pathology and Microbiology 4(9), 1-6 (2013).

45. Dua, A., Garg, G. \& Mahajan, R. Polyphenols, flavonoids and antimicrobial properties of methanolic extract of fennel (Foeniculum vulgare Miller). Euro. J. Exp. Bio. 3(4), 203-208 (2013).

46. Muhammad, A. et al. Molecular characterization of Fusarium oxysporum f. sp. cubense (FOC) tropical race 4 causing panama disease in cavendish banana in Pakistan. Pak. J. Agri. Sci. 54(1), 
DOI: https: //doi. org/10. 21162/ PAKJAS/17.4674 (2017).

47. Sati, S.C. \& Joshi, S. Antibacterial potential of leaf extracts of Juniperus communis L. from Kumaun Himalaya. African Journal of Microbiology Research 4(12), 1291-1294 (2010).

48. Bajpai, V. K. \& Kang, S. C. Antifungal activity of leaf essential oil and extracts of Metasequoia glyptostroboides Miki ex Hu. J. Am. Oil Chem. Soc. 87, 327-336, DOI: 10.1007/s11746-009-1500-6 (2010).

49. Al-Rahmah, A. N., Mostafa, A. A., Abdel-Megeed, A., Yakout S. M., \& Hussein, S. A. Fungicidal activities of certain methanolic plant extracts against tomato phytopathogenic fungi. African Journal of Microbiology Research 7(6), 517-524, DOI:10.5897 / AJMR12. 1902 (2013).

50. Georgopoulos, S. G. \& Dekker, J. Detection and measurement of fungicide resistance general principles. FAO Plant Prot. Bull. 30, 39-42 (1982).

51. Siripornvisal, S. Antifungal activity of ajowan oil against Fusarium oxysporum. KMITL Sci. Tech. J. 10(2), (2010).

52. Egua, M. O., Etuk, E. U., Bello, S. O. \& Hassan, S. W. Antidiabetic potential of liquid-liquid partition fractions of ethanolic seed extract of Corchorus olitorious. Journal of Pharmacognosy and Phytotherapy 6(1), 4-9, DOI: 10.5897/JPP2013.0294 (2014).

53. Bouson, S., Krittayavathananon, A., Phattharasupakun, N., Siwayaprahm, P. \& Sawangphruk, M. Antifungal activity of water-stable copper-containing metal-organic frameworks. R. Soc. open sci. 4, 170654, http://dx.doi.org/10.1098/rsos.170654 (2017).

54. Magaldi, S. et al. Well diffusion for antifungal susceptibility testing. International Journal of Infectious Diseases 8, 39-45, DOI:10.1016/j.jid.2003.03.002 (2004).

55. Smith, L. J., Smith, M. K., Tree, D., Keefe, D. O. \& Galea, V. J. Development of small-plant bioassay to assess banana grown from tissue culture for consistent infection by Fusarium oxysporum f. sp. cubense. Australasian Plant Pathology 37, 171-179 (2008).

56. Nel, B., Steinberg, C., Labuschagne, N. \& Viljoen, A. Evaluation of fungicides and sterilants for potential application in the management of fusarium wilt if banana. Crop Protection 26, 697-705, DOI:10.1016/j.cropro.2006.06.008 (2007).

57. Vicente, L. P., Dita, M. A. \& Martínez- de la Parte, E. Prevention and diagnostic of fusarium Wilt (Panama disease) of banana caused by Fusarium oxysporum f. sp. cubense tropical race 4 (TR4). Technical manual prepared for the regional training workshop on the diagnosis of fusarium wilt organized by FAO regional office of the Caribbean and CARDI on 5-9 May in St. Augustine, Trinidad and Tobago. 74pp, http:// www.

fao.org/fileadmin/templates/agphome/documents/Pests_Pesticides/caribbeantr4/13Manual Fusarium.pdf (2014).

58. Safdar, M. N. et al. Extraction and quantification of polyphenols from kinnow (Citrus reticulate L.) peel using ultrasound and maceration techniques. Journal of food and Drug analysis 25, 488-500 (2017). 
59. Gurib-Fakim, A. Medicinal plants: Traditions of yesterday and drugs of tomorrow. Molecular Aspects of Medicine 27(1), 1-93 (2006).

60. Yuan, H., Ma, Q., Ye, L. \& Piao, G. The traditional medicine and modern medicine from natural products. Molecule 21, 559, DOI:10.3390/molecules21050559 (2016).

61. Adekunle, A. S. \& Adekunle, O. C. Preliminary assessment of antimicrobial properties of aqueous extract of plants against infectious diseases. Biology and Medicine 1(3), 20-24 (2009).

62. Lengai, G. M. W., Muthomi, J.W. \& Mbega, E. R. Phytochemical activity and role of botanical pesticides in pest management for sustainable agricultural crop production. Scientific African 7:e00239 (2020).

63. Raveau, R., Fontaine, J. \& Sahraoui, A. L-H. Essential oils as potential alternative biocontrol products against plant pathogens and weeds: a review. Foods 9:365, DOI:10.3390/foods9030365 (2020).

64. Srivastava, S. et al. In vitro evaluation of carbendazim 50\% WP, antagonists and botanicals against Fusarium oxysporum f.sp. psidii associated with rhizosphere soil of guava. Asian J. Plant Pathol. 5, 46-53 (2011).

65. Yuliar, N. Y. A. \& Toyota, K. Recent trends in control methods for bacterial wilt diseases caused by Ralstonia solanacearum. Microbes and Environments 30(1), 1-11 (2015).

66. Sharma, A., Joshi, S. \& Kumar, N. Antioxidant and antibacterial properties of leaves of Elaeocarpus sphaericus Roxb. and Pinus wallichiana from Uttarakhand region of India. International Journal of Green Pharmacy 9(4), 246 (2015).

67. Rahman, T. U., Uddin, G., Khattak, K. F., Liaqat, W. \& Choudhary, M. I. Antibacterial, antifungal, insecticidal and phytotoxic activities of leaves of Pinus wallachiana. J. Chem. Pharm Res. 8(1), 420424 (2016).

68. Khoddami, A., Wilkes, M.A. \& Roberts, T. H. Techniques for analysis of plant phenolic compounds. Molecules 18, 2328-2375, DOI: 10.3390/ molecules 18022328 (2013).

69. Dziedzinski, M., Kobus-Cisowska, J. \& Stachowiak, B. Pinus species as prospective reserves of bioactive compounds with potential use in functional food-current state of knowledge. Plants 10:1306, https:// doi.org/10.3390/plants10071306 (2021).

70. Willför, S., Ali, M., Karonen, M., Reunanen, M., Arfan, M. \& Harlamow, R. Extractives in bark of different conifer species growing in Pakistan. Holzforschung 63, 551-558 (2009).

71. Karapandzova, M. et al. Flavonoids and other phenolic compounds in needles of Pinus peuce and other pine species from the Macedonian flora. Natural Product Communications 10(6), 987-990 (2015).

72. Naeem, I., Taskeen, A., Mubeen, H. \& Maimoona, A. Characterization of flavonols present in barks and needles of Pinus wallichiana and Pinus roxburghii. Asian J. Chem. 22(1), 41-44 (2010).

73. Maimoona, A. et al. Analysis of total flavonoids and phenolics in different fractions of bark and needle extracts of Pinus roxburghii and Pinus wallachiana. Journal of Medicinal Plants Research. 5(13), 2724-2728, http:// www. academicjournals. org/JMPR (2011). 
74. Yesil-Celiktas, O. et al. Determination of polyphenolic constituents and biological activities of bark extracts from different Pinus species. J Sci Food Agric. 89, 1339-1345 (2009).

75. Zuo, C. et al. The toxic mechanism and bioactive components of chinese leek root exudates acting against Fusarium oxysporum f. sp. cubense tropical race 4. Eur. J. Plant Pathol. 143, 447-460, DOI: 10.1007/s10658-015-0697-5 (2015).

76. Mackesy, D. \& Sullivan, M. CPHST Pest Datasheet for Fusarium oxysporum f.sp. cubense tropical race 4. USDA-APHIS-PPQCPHST (2015).

77. Moses, A. O. Diversity of Fusarium oxysporum f. sp. cubense in Mozambique and associated in vitro response to fungicides, biocontrol-agents and phenolic compounds. M.Sc. Diss., Eduardo Mondlane University, Maputo, Mozambique (2016).

\section{Figures}
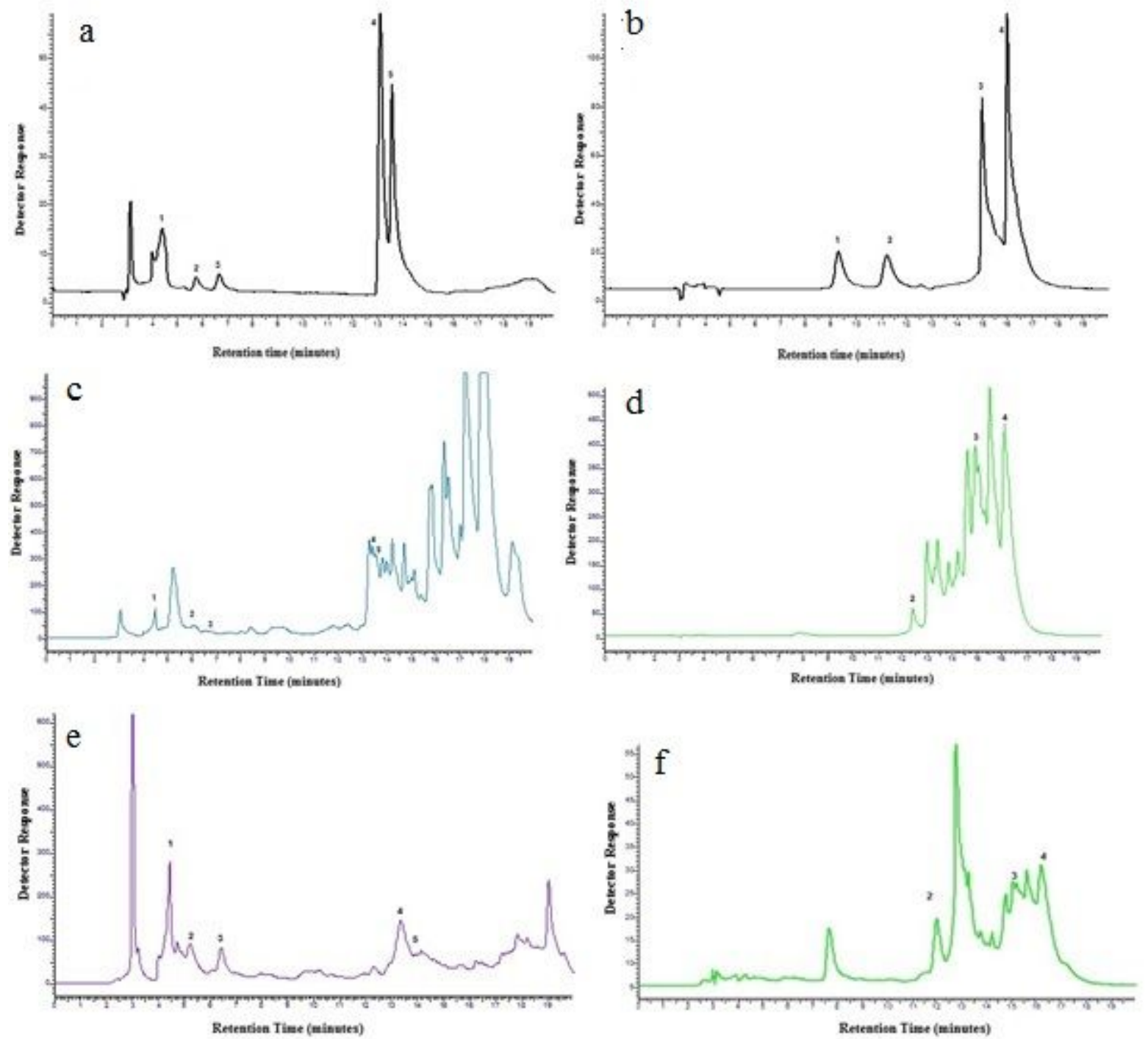

Figure 1 
(a) Typical chromatogram of polyphenol standards (100ppm) at $285 \mathrm{~nm}$. 1= Gallic acid, 2= Catechin, 3= Epicatechin, 4= Coumaric acid, 5= trans-Ferulic acid. (b) Typical chromatogram of flavanoids (100ppm) at 370nm. 1= Rutin, 2= Myrecitin, 3= Quercetin, 4= Kaempferol (c) Chromatogram obtained for ethyl acetate fraction at $285 \mathrm{~nm}$. 1=Gallic acid, 2=Catechin, 3= Epicatechin, 4= Coumaric acid, 5= trans-Ferulic acid, (d) Chromatogram obtained for ethyl acetate fraction of at $370 \mathrm{~nm}$. 2= Myrecitin, 3= Quercitin, 4=Kaempferol, (e) Chromatogram obtained for $\mathrm{n}$-butanol fraction at $285 \mathrm{~nm}$. 1=Gallic acid, 2=Catechin, 3= Epicatechin, 4= Coumaric acid, 5= trans-Ferulic acid, $(f)$ Chromatogram obtained for $n$-butanol fraction at 370nm. 2= Myrecitin, 3= Quercitin, 4=Kaempferol

\section{Supplementary Files}

This is a list of supplementary files associated with this preprint. Click to download.

- SupplementarydataQuratUIAin.docx 